\title{
Chapter 16 \\ From Policy to Practice in Higher Education: \\ Cross-Cutting Issues in Indigenous Pathways, Transition and Participation
}

\author{
Jack Frawley, Steve Larkin, and James A. Smith
}

\section{Introduction}

An aim of this volume is to acknowledge the diverse approaches and strategies used to support and enhance pathways and transitions into higher education for Indigenous learners. Authors have approached this from various standpoints and so this book has a focus on social justice and equity issues in Australian and international contexts, and cross-cuts a range of disciplines including humanities, social sciences, education and public policy. Issues raised in this volume include transitions and pathways policy, theory and practice, but are very much grounded in the need for a transformative academy, one which truly engages with communities and has an intercultural foundation. Nakata (2002) views the academy as a 'cultural interface' where there is an intersection of Western and Indigenous domains... the place where we live and learn, the place that conditions our lives, the place that shapes our futures and more to the point the place where we are active agents in our own lives where we make our decisions - our lifeworld'. The 'cultural interface' has commonalities with the concepts of 'both ways' (Wunungmurra 1989; Marika et al. 1992; Ober and Bat 2007) and 'interculturalism' (Abdallah-Pretceille 2006; Coll 2004; Frawley and Fasoli 2012) as these are concerned with similar notions of space

\footnotetext{
J. Frawley $(\bowtie)$

National Centre for Cultural Competence, University of Sydney, Sydney, NSW, Australia e-mail: jack.frawley@sydney.edu.au

S. Larkin

Pro Vice-Chancellor Indigenous Education and Research, University of Newcastle,

Newcastle, NSW, Australia

e-mail: steven.larkin@newcastle.edu.au

J.A. Smith

Office of the Pro Vice-Chancellor (Indigenous Leadership), Charles Darwin University,

Darwin, NT, Australia

e-mail: James.Smith3@cdu.edu.au
} 
where systems, organisations, communities and people meet and interact, where there is balance, where knowledge is negotiated and where new knowledge is shared equally. This is the challenge for higher education: that within the cultural interface context, each university is a place for everyone.

\section{From Policy}

How social policy and theory is applied to the context of Indigenous higher education practice is addressed by several authors in this volume. This ranges from making higher education more accessible through to consideration around pedagogy and curriculum within the academy. This volume exists within the dual contexts of national higher education policies and institutional ones. At a national level, there is a call for a stronger alignment between national equity policies in higher education and Indigenous higher education, especially using a strengths-based approach. A strengths-based approach to policy, amongst other things, emphasises equity for Indigenous students and also the provision of meaningful pathway choices and support during transitions. Smith, Trinidad and Larkin adopt 'a strengths-based perspective to explain what the future possibilities and opportunities might be in promoting greater cohesion, integration and interdependence between equity and Indigenous higher education agendas in Australia'. Smith, Larkin, Yibarbuk and Guenther et al. state that in order to improve Indigenous community engagement in the higher education sector there is a need to move beyond the rhetorical language of many policies and actively engage with Indigenous communities. At an institutional level, Rigney provides an example of where an institutional policy of a wholeof-university approach has influenced a university's structure, culture and identity. This required assembling resources; engaging learners; working together; building confidence; and striving for excellence and equity to achieve a transformative academy committed to educational and social change. Frawley provides an example of where tensions can exist when a transformative vision is constrained by regulated policies and practice, in this case institutional policies associated with the Recognition of Prior Learning for Advanced Standing.

\section{To Practice}

The concept of student success, and the issues around it, is a thread running throughout this volume. Ober and Frawley locate a story of success within self-efficacy theory. Bandura (1997, p. 3) defined self-efficacy as 'the belief in one's capabilities to organise and execute the courses of action required to produce given attainments'. Put simply it is the belief about one's own ability to be successful in the performance of a task. Ottmann believes that her higher education success would not have been possible if she did not have the unconditional support of her friends and family, 
and a desire to affect positive change for First Nations communities. Viewed through a self-efficacy lens, Ottmann is drawing on two sources: the first, verbal persuasion which is understood as an individual's susceptibility to being persuaded of capability (or incapability) to perform certain behaviours; that is, it is easier to sustain efficacy if significant others convey belief in one's capability. The second, physiological states suggests that one way to raise self-efficacy is to improve physical and emotional well-being and reduce negative emotional states. From the physiological source of self-efficacy, there is an emerging subset: a focus on a person's emotional motivation to succeed in order to give something back to the community, which is linked to cultural norms such as the spirit of giving, reciprocity, relationships and responsibility. Ottmann states her desire to succeed in order to give back to her community.

Fredericks et al. argue that enabling programs pedagogy and mode of delivery need to be considered 'within the framework of the institutional ethos and drivers for implementation'. Understanding and responding to the socio-political and organisational context of universities is fundamental to achieving this. The application of cultural competency within higher education spaces in Australia is described in detail by Sherwood and Russell-Mundine in the context of the national Centre for Cultural Competency at the University of Sydney where the focus has extended beyond Indigenous communities to include other marginalised groups. There is support for the valuing of Indigenous Knowledge (IK) in the academy but an urgent need for universities to move on this. Ottmann states that universities need to build a system that is inclusive of IK. Frawley believes that this would benefit both Indigenous and non-Indigenous students to interact productively and creatively across cultural boundaries, and engage meaningfully and constructively with each other and with the academy'. Tachine calls for the academy to be informed by cultural sustaining pedagogies while Frawley, Smith and Larkin suggest a pedagogy 'that provides better opportunities for negotiation between Indigenous and nonIndigenous meanings'. With an increasing movement towards online technologies, Lee et al. and Prayaga et al. believe that this might provide a significant opportunity to make higher education accessible and allow people to remain in their communities.

\section{Research Directions}

The research agenda in the context of Indigenous pathways and transitions into higher education remains a focus, and this volume has identified several gaps in the research. Wilks et al. argue that 'university educators need to develop culturally informed principles around their practice, and the related practical strategies to enact them, to underpin the development of a framework in higher education involving these elements'. They argue that encouraging success recognises that learning is not an individual activity and that achieving success relies on several enablers, concluding that greater energy needs to be put into finding out why the higher education 
sector is often failing Indigenous students. In discussing enabling programs Pitman et al. argue that greater work needs to be done by policymakers at a national level for greater investment as there 'is a demonstrable link between participation in enabling programmes and subsequent participation in higher education'. Pitman et al. suggest that investigating the factors that improve or reduce odds of success for Indigenous students completing their HE studies is required, and they identify several research issues around enabling programs. This research agenda includes investigating the impact of enabling programs on undergraduate retention rather than success; whether enabling programs provide Indigenous students with comparable levels and types of support; and, the success, impact and validity of the different approaches to Indigenous specific and generic enabling programs. At a community level, Guenther et al. believe that aspiration for university must be modelled from a young age and that programs that support local parents to be more involved in remote schools are essential and tremendously important. Guenther et al. assert that the impact of participation in higher education needs to involve research beyond the students to include parents, students and whole communities.

\section{Conclusion}

The importance of understanding and responding to Indigenous pathways and transitions in higher education in Australia, and indeed globally, has been discussed throughout this book. While there is a growing evidence base about how best to support Indigenous pathways and transitions into higher education, there is still much to be achieved. In fact, a commitment to more robust and comprehensive evaluations of existing programs and policies at national, state and local levels is urgently required. This is important to better understand and address the inherent complexities Indigenous students face when attempting to navigate access into, and through, higher education. This also needs to be mirrored by high-quality and wellfunded action-oriented research to develop strategies that make a difference. Not strategies on a page or a bookshelf, or that can shift from year to year to meet political funding cycles, but strategies that are carefully planned and scaffolded to withstand detrimental changes to the social, political, economic and organisational environment. Drawing on the evidence presented throughout this book, it is clear that policymakers, researchers, practitioners and Indigenous students (and their families and communities) need to work together to achieve positive and sustainable change. If we truly want to see Indigenous higher education outcomes improve in Australia, then providing opportunities to connect with, and learn from, one another across research, policy and practice domains is imperative. This book acts as a catalyst to continue this journey in earnest. 


\section{References}

Abdallah-Pretceille, M. (2006). Interculturalism as a paradigm for thinking about diversity. Intercultural Education, 17(5), 475-483.

Bandura, A. (1997). Self-efficacy: The exercise of control. New York: Freeman.

Coll, A. C. (2004). The intercultural challenge. Bangalore: Pipal Tree.

Frawley, J., \& Fasoli, L. (2012). Working together: Intercultural leadership capabilities for bothways education. School Leadership \& Management, 32(4), 309-320.

Marika, R., Ngurruwutthun, D. \& White, L. (1992). Always together, yaka ga na: Participatory research at Yirrkala as part of the development of a Yolngu education. Convergence 25, No. 1: 23-39.

Nakata, M. (2002). Indigenous knowledge and the cultural interface: Underlying issues at the intersection of knowledge and information systems. IFLA Journal, 28(5-6), 218-221.

Ober, R., \& Bat, M. (2007). Paper 1: Both-ways: The philosophy. Ngoonjook: A Journal of Australian Indigenous Issues, 31, 64-86.

Wunungmurra, W. (1989). Dhawurrpunaramirr - Finding the common for a new Aboriginal curriculum. Ngoonjook: A Journal of Australian of Australian Indigenous Issues, 2(12).

Open Access This chapter is licensed under the terms of the Creative Commons Attribution 4.0 International License (http://creativecommons.org/licenses/by/4.0/), which permits use, sharing, adaptation, distribution and reproduction in any medium or format, as long as you give appropriate credit to the original author(s) and the source, provide a link to the Creative Commons license and indicate if changes were made.

The images or other third party material in this chapter are included in the chapter's Creative Commons license, unless indicated otherwise in a credit line to the material. If material is not included in the chapter's Creative Commons license and your intended use is not permitted by statutory regulation or exceeds the permitted use, you will need to obtain permission directly from the copyright holder. 